\title{
Effect of shrub encroachment on their sub-canopy soil and vegetation properties
}

\author{
Reza Erfanzadeh ${ }^{1}$, Moslem Yazdani $^{1}$, and Asghar Saleh Mosleh Arani ${ }^{2}$ \\ ${ }^{1}$ Tarbiat Modares University \\ ${ }^{2}$ Yazd University
}

December 16, 2020

\begin{abstract}
Shrub encroachment (SE) has been occurring and studied worldwide over the last century. What remains to be investigated is how soil and vegetation characteristics vary under canopy of different species of shrubs for restoration goals. Thus, this study aimed to compare the effect of three shrub species (Amygdalus scoparia, Ebenus stellata, and Daphne mezereum) on soil and vegetation characteristics under their canopies in semiarid rangelands in Iran for restoration purposes of degraded areas. Fifteen sites were randomly selected in such three shrub species which were found close to each other in each site. Soil and vegetation characteristics were measured under the three shrubs, comparing with outside the shrub canopies (control). One-way ANOVA and non-metric dimensional scaling were used to clarify the differences of the effects of different shrub species on sub-canopy soil and plants. The results indicated that the effect of different species of shrubs on soil properties was not equal, more pronounced by A. scoparia. Similarly, the highest value of herbaceous Shannon-Wiener diversity index was recorded under A. scoparia (2.07) as compared with D. mezerum (1.76), E. stellata (1.41). The highest and lowest values of Menhinick richness index were observed under A. scoparia (3.43) and E. stellata (1.46), respectively. Compared with two other shrubs, a taller canopy in A. scoparia $(3.50 \mathrm{~m}$ vs. $2.60 \mathrm{~m}$ and $1.83 \mathrm{~m})$ probably led to greater litter input by the shrub. Different effects of different species of shrubs on sub-canopy soil and vegetation should be considered in the restoration projects of degraded semiarid rangelands.
\end{abstract}

\section{Introduction}

Shrub encroachment (SE) has been a serious concern and extensively studied by ecologists. According to our literature review, SE studies have globally targeted different ecosystems i.e. arid (Eldridge et al., 2011; Soliveres et al., 2014), semiarid (Gazol et al., 2012; Kulmatiski et al., 2013; Foronda et al., 2019), subalpine grasslands (e.g. Ding et al., 2019), temperate grasslands (e.g. Li et al., 2019), and mesic areas (Briggs et al., 2005) such as savanna (Wiegand et al., 2005; Kulmatiski et al., 2013; Stevens et al., 2017), steppe (e.g. Chen et al., 2014) and prairie (e.g. Briggs et al., 2005). These global studies revealed that soil properties are the primary dependent variables in response to the extent of SE (see also Li et al., 2016).

Previous studies have shown that within landscape-level, the effects of shrub on understory soil are varied, ranging from positive to negative or neutral (Eldridge et al. 2011; Du et al., 2016). Many studies have reported reductions in soil nutrient (e.g. Guidi et al., 2014), and increasing soil erosion following SE (Parizek et al., 2002). Other studies, however, have shown that SE can substantially enhance soil nutrient acquisition, or amplify soil biota diversities (Maestre et al. 2009; Gómez-Rey et al., 2013; Throop et al., 2013; Blaser et al., 2014). In patch-level effects, evidence has reported generally positive effects of individual shrubs on their sub-canopy soil conditions (e.g. Ding et al., 2019). For instance, the well-known term of "fertile island" has been defined for shrubs due to positive effects of its individuals on sub-canopy soil (Ren et al., 2008; Kondo et al. 2012). However, effects of different species of shrubs on their sub-canopy soil characteristics have remained poorly understood. 
Maintaining the plant diversity is a major challenge in plant community ecology (Gonzalez and Ghermandi, 2019). Although classical studies on this issue have focused on the negative plant-plant interactions, more recent studies have considered the importance of the positive interactions, such as the nurse effect of larger plants on smaller ones (e.g. Baldelomar et al., 2019). Although at the landscape level, shrubs could reduce plant diversity (Ratajczak et al., 2012), at the patch level, they are known as nurse plants due to their positive effects on sub-canopy and increasing plant diversity. Nurse plants are described as plants that facilitate the growth and development of other plant species beneath their canopies as they offer benign microhabitats which are more favorable for seed germination and/or seedling recruitment than their surrounding environment. Thus, nurse plants have been mainly considered for restoring vegetation in terrestrial ecosystems that suffer harsh natural conditions such as arid and semiarid areas (Ren et al., 2008). Shrubs, as nurse plants, alter vegetation properties under their canopies with seed trapping, facilitating seed production by understory plants, increasing soil seed bank, increasing soil moisture, protecting the surface soil from erosion, and adding litter into the soil (García-Sánchez et al., 2012; Erfanzadeh et al., 2014b; Mussa et al., 2016; Erfanzadeh et al., 2019). Although the functions of shrubs have been studied in different ecosystems around the world, the effect of their nursing role in sub-canopy plants has been hardly compared between different species of shrubs.

It can be supposed that depending on the structure and feature of shrubs (erect or recumbent, dense or open canopy, having single or multiple stems), they could play different roles in changing the soil properties and vegetation characteristics we tested in this study. Accordingly, the main objective of this study was to assess the effects of three species of shrubs on soil nutrients and vegetation characteristics in semiarid areas. We hypothesized that the extent to which shrubs affected soil and vegetation is dependent on the species of shrubs.

\section{Materials and methods}

Introducing the study area

The study was conducted in Marvast semiarid rangelands in Yazd province, Iran. The average annual rainfall is $250 \mathrm{~mm}$ which is maximum in January $(58.7 \mathrm{~mm}$ ) and minimum in July and August (without rainfall). The average annual temperature is $17.5^{\circ} \mathrm{C}$ with average annual maximum temperature $28.3^{\circ} \mathrm{C}$ and average annual minimum temperature of $0.7^{\circ} \mathrm{C}$. According to the De Martonne's classification, the climate is determined as "semiarid". Soils are the Brown steppe, predominant soils in Iran. They have a very weak, often thick, $\mathrm{A}_{1}$ horizon with an organic matter content of about 1\% or more (Dewan and Famouri, 1964).

Shrubs are dominant in the area (Eskandarie, 2012). SE has been described as an increase in the density of woody plants (e.g. Wiegand et al., 2005). According to personal observation and communication with native people and pastorals, the cover and density of shrubs have increased during the recent years, showing a SE into the rangelands (Geravand et al., 2016).

Shrub and site selection

Three dominant shrubs were selected with different features and architectures in the canopy, together with surrounding herbaceous vegetation (hereafter called control).

1. Amygdalus scoparia Spach. (Rosaceae family) is a wild species of almond which occupies large areas in many parts of central Iran and its neighboring countries. The oil of the A. scoparia is extracted and used due to its fatty acid composition which is comparable to that of olive oil (Sorkheh et al., 2016). The plant is attractive for grazing animals due to its shade, fruits, and high palatability of leaves. It is a deciduous large shrub which grows to a height of up to $6 \mathrm{~m}$, having a single-elongate main stem. It produces numerous long and green branches. Fruits are drupes and are 1 to $1.5 \mathrm{~cm}$ long and $0.5 \mathrm{~cm}$ wide. They ripen and dehisce at the end of July (Fig. 1).

2. Ebenus stellata Boiss. (Fabaceae family) is a thorny shrub with a height of 30-120 cm, with short and oblong-leafy branches and ternate leaves that are alternate and covered with dense silk flakes. This species grows in large parts of Iran including Kerman, Yazd, Esfahan, Fars, and Hormozgan provinces as 
well as some dry and semi-dry regions of world (e.g. Oman and India countries). The canopy structure is open with thorny branches (Fig. 1).

3. Daphne mezereum L. (Thymelaeaceae family) is a rounded-upright deciduous shrub with an erect and bushy habit which typically grows to $1.5 \mathrm{~m}$ tall. All parts of this plant are poisonous to humans if ingested, especially the fruits, sap, and bark. Thus, this shrub is unpalatable for grazing animals. Nevertheless, fruits are attractive to birds with no resulting ill effects. This species is found globally in dry and semi-dry areas as well as in the provinces located in central Iran (Mozaffarian, 2012) (Fig. 1).

Fifteen sites were randomly selected in the study area. In each site, all three shrub species were close to each other (see 1 Fig. 1). Thus, the topographical conditions were equal for growing the three shrubs and related controls in each site, giving an opportunity for statistical comparison of sub-canopy soil and vegetation characteristics between shrubs.

Soil sampling and analyses

Soil sampling was done in April 2018 during the peak of plant biomass production. According to the previous findings that the main effects of shrubs would be changes in topsoil properties (e.g. Li et al., 2016; Zhou et al., 2017), we thus collected soil samples from the topsoil (see also Hu et al., 2018; Ding et al., 2019). Under the canopy of each individual shrub, 10 soil cores were randomly collected to a depth of $20 \mathrm{~cm}$, with a $5 \mathrm{~cm}$ diameter auger and pooled for each individual. In this way, three soil samples were collected in each site for three species of shrubs (totally 45 soil samples) and one for each control (totally 15 soil samples). The locations of control areas were selected according to the prevailing wind direction in the area. Due to the prevailing north-western winds in the study area, to eliminate the effects of shrub litterfall on soil and vegetation in controls, we collected 10 soil cores in the opposite direction to the prevailing wind (southeastern) with respect to the shrubs and at a location beyond the influence area of any other shrubs at a minimum distance of $100 \mathrm{~cm}$ from the shrub canopies in each site (Casal et al., 2013). Roots, shoots, and pebbles in each sample were separated by hand and discarded after which the soil samples were transported to the laboratory. The air-dried samples were sieved, the smaller roots and coarse gravel $(>2 \mathrm{~mm})$ were removed through sieving, and the $<2 \mathrm{~mm}$ soil was used to examine the effects of shrub species on soil properties. Soil $\mathrm{pH}$ was determined using an Onion Ionalyzer Model $901 \mathrm{pH}$ meter in a 1:2.5, soil: water solution. Electrical conductivity (EC) was determined from a soil extract with an EC meter, following the manufacturer's instructions. The available $\mathrm{K}, \mathrm{Ca}$, and $\mathrm{Mg}$ contents (with ammonium acetate extraction at $\mathrm{pH} 9$ ) were determined by an atomic absorption spectrophotometer (AAS) and Cation exchange capacity (CEC) with flame photometer (Bower et al., 1952). The total nitrogen (N) was measured using a semi Micro-Kjeldhal technique (Bremer and Mulvaney, 1982). The available $\mathrm{P}$ was determined via a spectrophotometer using Olsen method (Homer and Pratt, 1961). Soil organic matter (OM) was determined through Walkey-Black technique (Allison, 1975; Erfanzadeh et al., 2014a).

Vegetation sampling and analyses

In the growth season (April 2018), the mean density (number $\left./ \mathrm{m}^{2}\right)$, mean production $\left(\mathrm{kg} / \mathrm{m}^{2}\right.$ ), and mean cover $(\%)$ of each plant species growing under the canopy of each shrub and surrounding area (control) were determined using quadrats $0.5 \mathrm{~m} \times 0.5 \mathrm{~m}$. Since no clonal species were observed in the area, estimation of plant density for all herbaceous species was feasible. We used the methodology of "clipping and weighing" for estimating the plant production of each herbaceous species (Heady and Child, 1994). The herbaceous species in each plot were clipped using a shear, and then weighed after oven drying, after which the weight was calculated per $\mathrm{m}^{2}\left(\mathrm{gr} / \mathrm{m}^{2}\right.$ for plant productions). The number of individuals was also counted in the quadrats for each plant species and transferred into the number per $\mathrm{m}^{2}$. Areal cover percentages of plants were visually estimated in each quadrat. The number of quadrats under each shrub individual varied according to the size of canopy of shrubs between two (for smallest ones) and four (for largest ones). We also estimated the mean canopy surface of shrubs on ground and the height of each individual shrub using a meter tape.

In addition, placing a thermometer (Marmonix MST 325 model) on soil, the mean soil surface temperature was measured in multiple measurements (10 points) beneath each shrub and control. The time of recording 
the soil surface temperature was the same for four locations (under three shrubs and control) in each site.

Plant diversity and richness indices were calculated for each individual under-shrub using plant cover data. The Shannon index is commonly used to characterize the diversity of communities; it is sometimes referred to as the Shannon-Wiener index (Equation 1) (Chernov et al., 2015).

Equation $1 \mathrm{H}^{\prime}=\sum_{i=1}^{s}$ pilogpi

Where $\mathrm{p}_{\mathrm{i}}$ is the relative abundance of the ith taxon, and $\mathrm{S}$ denotes the number of detected taxon.

Another diversity index frequently used in ecology is the Simpson index, which is commonly determined as the probability of two plant species belonging to different taxa randomly selected from an indefinitely large community. The Simpson index is calculated from Equation 2 (Chernov et al., 2015).

Equation $2 \mathrm{~S}_{\mathrm{I}}=\sum_{i=1}^{s} \frac{n i(n i-1)}{N(N-1)}$

Where $\mathrm{n}_{\mathrm{i}}$ is the individual number of each plant species in the taxon, and $\mathrm{N}$ denotes the total number of all individuals of all plant species.

In addition, a large number of species richness indices have been invented, each providing a value to show richness in a habitat, among which the Menhinick index was used a simple measure of species richness (Equation 3) (Hammer et al., 2001).

Equation $3 \mathrm{M}_{\mathrm{I}}=(\mathrm{S}) / \sqrt{N}$

Where, $\mathrm{S}$ is the total number of species and $\mathrm{N}$ denotes the total number of individuals in the sample.

All diversity and richness indices were calculated using the Past software.

\section{Data statistical analysis}

Firstly, normality of data (soil and vegetation characteristics) was examined using the Kolmogorov-Smirnov test and homogeneity of variance using Levene's test. To evaluate the effect of shrub species on soil properties and, plant diversity and richness, one-way ANOVA and LSD mean comparison tests were used. All statistical analyses were performed in SPSS software ver. 16.

Secondly, in order to compare the combination of soil properties under three shrubs and surrounding area, the non-metric multidimensional scaling (NMDS) was performed (Kottler Gedan, 2019) using the package 'vegan' (Oksanen, 2019) in R (R Core Team, 2018).

In addition, using the cover percentage of plants, the compositions of vegetation were compared between four locations (three under the canopy of three shrub species and one in the control) using additional NMDS performing.

Results Variation of soil properties under the shrubs

The results of one-way ANOVA revealed that with the exception of $\mathrm{Ca}$ and $\mathrm{Mg}$, all soil properties were significantly different $(\mathrm{P}<0.05)$ between four locations (under three shrubs and control) (Table 1 ).

The $\mathrm{pH}$ significantly decreased with shrub canopies with the lowest value under A. scoparia (7.99) (Fig. 2). The highest $\mathrm{pH}$ value was observed in the control (8.34).

Significant differences of EC, N, and $\mathrm{P}$ were observed between four locations with the highest values under $A$. scoparia $(0.28 \mathrm{Ms} / \mathrm{cm}, 0.57 \%$ and $67.7 \mathrm{mg} / \mathrm{kg}$, respectively) and the lowest values in control $(0.12 \mathrm{Ms} / \mathrm{cm}$, $0.16 \%$ and $10.57 \mathrm{mg} / \mathrm{kg}$, respectively). Although the values of $\mathrm{K}$ and $\mathrm{OM}$ were not significantly different between three shrubs, the lowest significant values of $\mathrm{K}$ and $\mathrm{OM}$ were found in the control with $257.9 \mathrm{mg} / \mathrm{kg}$ and $0.81 \%$, respectively (Fig. 2).

The highest mean soil surface temperature was recorded in control $\left(32.77^{\circ} \mathrm{C}\right)$ and the lowest under A. scoparia and D. mezerum $\left(19.09^{\circ} \mathrm{C}\right.$ and $17.93^{\circ} \mathrm{C}$, respectively). 
The NMDS results of soil properties separated and identified groupings of soil (Fig. 4). Axis 1 clearly separated soil under D. mezerum, A. scoparia and E. stellata from control. The second axis of the NMDS showed no separable grouping for the four locations (Fig. 3).

Variation of vegetation characteristics under the shrubs

In general, 65 plant species were recorded in the study area. Astraceae, Poaceae, and Papilianaceae were the most abundant families with 12, 10 and 7 species, respectively. Bromus tectorum and Galium aparine were found abundant and common in the four locations. The number of species beneath three shrubs and control was different with 43, 50, 30 and 31 species under D. mezerum, A. scoparia, E. stellata and control, respectively (Appendix S1).

The results showed that the highest and lowest values of Shannon-Wiener diversity index were observed beneath the $A$. scoparia and control with 2.07 and 1.10, respectively. In addition, the highest value of Simpson diversity index was recorded under A. scoparia (0.84) which was not significantly different from D. mezerum (0.80) and control (0.80), while the lowest value of Simpson diversity index was observed under E. stellata (0.55). The highest and lowest values of Menhinick richness index were observed under $A$. scoparia(3.43) and E. stellata (1.46), respectively (Table 2).

The greatest herbaceous production was observed under E. stellata $\left(64.76 \mathrm{gr} / \mathrm{m}^{2}\right)$ and lowest was found in the control $\left(16.09 \mathrm{gr} / \mathrm{m}^{2}\right)$ (Table 2$)$.

In addition, the mean surface of shrub canopies on ground was ca. $7.5 \mathrm{~m}^{2}, 5.5 \mathrm{~m}^{2}$, and $4.00 \mathrm{~m}^{2}$ for A. scoparia $D$. mezerum, and E. stellata, respectively, and amongst three shrubs, A. scoparia had the highest mean height with ca. $3.5 \mathrm{~m}$ compared with D. mezerum and E. stellata with ca. $2.60 \mathrm{~m}$ and ca. $1.83 \mathrm{~m}$, respectively (Table 2).

The NMDS results of vegetation cover identified groupings of species composition (Fig. 4). Axis 1 separated D. mezerum and A. scoparia from E. stellata and control. On the other hand, the second axis of the NMDS showed no separable grouping for the four locations.

DiscussionThe effect of shrubs on soil nutrients

Comparing the shrubs and control, our results indicated that the presence of shrubs increased the values of soil nutrition properties (OM, N, P and K). Many studies have found that shrubs increased soil OM (Blaser et al., 2014; Liu et al., 2015; Du et al., 2016; Li et al., 2016; Zeng et al., 2017; Ding et al., 2019), N (Blaser et al., 2014; Zeng et al., 2017; Ding et al., 2019), P (Hagos et al., 2005; Blaser et al., 2014; Ding et al., 2019) and K (Hagos et al., 2005; Ding et al., 2019), where our results supported these findings. Nutrient accumulation beneath shrubs as fertile islands in drylands is common and can provide opportunities for $\mathrm{C}$ and N enhancement. For instance, McClaran (2008) found that soil OM and N accumulation was one to eight times greater beneath Prosopis sp. than in the open grassland. Similarly, many other researchers reported that soils under shrubs are more fertile than soils from the surrounding grassland (Abdallah et al., 2012; Noumi, 2015). Xie (2004) stated that soil OM stocks can be enhanced by increasing the rate of litter addition to the soil. Thus, in our study area, the augmentation of nutrient properties in soil can be a result of a high input of plant litter amount by leaves and stems of shrubs and herbaceous species existing under the shrub canopies.

Among studied soil properties, lower $\mathrm{pH}$ levels (less alkaline) were observed beneath the three shrubs than control, which may be due to leaching of volatile acids from the foliage of these shrubs (Whitford, 1992). Eldridge (2011) analyzed the data of 244 case studies in 43 ecosystem attributes from different parts of the world and showed that $\mathrm{pH}$ declined with shrub.

Comparing three shrubs, significantly higher values of soil $\mathrm{N}$ and $\mathrm{P}$ and, and non-significantly higher values of soil $\mathrm{OM}, \mathrm{Mg}$ and $\mathrm{K}$ were observed under A. scoparia. Taller $(3.50 \mathrm{~m}$ vs. $2.60 \mathrm{~m}$ and $1.83 \mathrm{~m})$ canopy may be a reason for increasing litter input compared with the two other shrubs. Thus, a greater shrub litter mass would be likely to promote higher levels of microbial decomposition, leading to enhanced soil nutrient 
properties i.e. OM, N, K, P and Mg (see also McClaran et al., 2008; Eldridge et al., 2011). In addition, larger shrubs would be expected to support higher levels of biological activity as they provide a wider habitat (canopy area) and therefore more resources (e.g. seed, fruit, sap, flowers) for birds and mammals.

The effect of shrubs on vegetation characteristics

Comparing vegetation characteristics under three shrubs and control, shrubs generally increased the plant species diversity and richness. The most conservative explanation is that in semiarid lands, shrub shading may promote facilitation role due to its effects on reducing evapotranspiration and improving soil moisture (e.g. Maestre et al., 2003; Guo et al., 2019). Indeed, higher litter input combined with lower soil surface temperature under the canopies may create proper conditions for emergence, growth, and reproduction of a larger number of species due to increase in available soil moisture and decrease in soil surface evaporation, resulting in enhanced plant diversity and richness. Ghemandi (2019) reported that shrubs acted as nurse species increasing the richness in the non-degraded semiarid grassland and facilitating the seedling recruitment of important forage species in the degraded sites. Similarly, Foronda (2019) indicated that plant diversity in semiarid gypsum communities accumulated in the vicinity of shrubs. Also, Piper (2019) stated that shrubs facilitated the occurrence of many species in the plant community.

Among three shrubs, greater plant diversity and richness were found under A. scoparia. Several traits of shrubs could be important in relation to their functional outcome. Increases in the stature and size of A. scoparia may promote a higher diversity of understory canopies because of the "patch effect" (Erfanzadeh et al., 2014b) and the increase in habitat heterogeneity under shrub canopies (Maestre and Cortina 2005; Iyengar et al., 2017). Garner and Steinberger (1989) reported that a higher shrub height compared with shorter shrubs and control indicated the potential for shrubs to alter the microclimate, and capture mobile resources such as airborne sediments, and therefore their potential to create fertile islands and increasing plant diversity under the canopy. Further, the shrub produces nests for birds and small animals and may determine animal use and habitat, and therefore deposits of exogenous resources such as feces and carcasses (Maestre et al., 2009) and, deposits seeds through epizoochory and endozoochory (Chuong et al., 2016), resulting an increase in plant diversity and richness. Similarly, in semiarid steppes from the Mediterranean Basin, increases in shrub cover and size were associated with higher species richness and diversity of vascular plants (Maestre et al., 2009).

Although the diversity and richness of plant species were highest under $A$. scoparia, the greatest green plant production was found beneath the canopy of E. stellata. The data showed that some annual species (e.g. Bromus danthonia and B. tectorum ) consisted to a large part of plant production under E. stellatawhile they were produced in a very smaller amount of biomass under the two other shrubs.

Finally, a literature review found that the three shrubs are probably different in negative allelopathic impacts on herbaceous plants under their canopies. D. mezerum produced a secondary metabolite, containing various toxic compounds, including daphnetoxin and mezerein (Chiej, 1984). While, lack of acute toxicity was reported in E. stellata (e.g. Khodaparast et al., 2012) and A. scoparia (e.g. Zibaeenezhad et al., 2017)

Grouping of soil properties and vegetation characteristics by NMDS

The results of NMDS divided the soil properties into recognizable groups including shrubs and control. This means that the soil under the three shrubs was completely segregated from control; dissimilarity of the soil between shrubs and control was greater than between three shrubs. Thus, any species of shrub is able to change (promote) soil and should be considered in the conservation projects in semiarid areas. Conversely, grouping of vegetation characteristics was less pronounced by NMDS. Thus, it can be concluded that the sensitivity of soil properties to the shrubs might be higher than of vegetation.

\section{Conclusions}

Natural regeneration of herbaceous species in disturbed sites may be facilitated by increasing the cover of shrub species. Thus, they could be used as nurse plants during the first stages of restoration project. We believe that increasing the cover and encroachment of shrub species should not be a concern for managers. 
Conversely, recovery of herbs can also be initiated through conservation and extension of shrubs. Nevertheless, the extent to which shrubs affect soil and vegetation characteristics is dependent not only on the presence of shrubs, but also on the species of shrubs. Thus, different functions of various species of shrubs on soil and vegetation should be considered in the restoration projects of degraded rangelands.

\section{References}

Abdallah F, Noumi Z, Ouled Belgacem A, Michalet R, Touzard B, Chaieb M. 2012. The influence of Acacia tortilis (Forssk.) ssp. raddiana (Savi) Brenan presence, grazing, and water availability along the growing season, on the understory herbaceous vegetation in southern Tunisia. Journal of Arid Environments $\mathbf{7 6}$ : $105-114$.

Allison LE. 1975. Organic carbon. - In: Black, C. A. (Ed.), Methods of soil analysis. American Society of Agronomy, Part 2, Madison, WI: 1367-1378.

Baldelomar M, Atala C, Molina Montenegro MA. 2019. Top-down and bottom-up effects deployed by a nurse shrub allow facilitating an endemic Mediterranean orchid. Frontiers in Ecology and Evolution 7 : 466.

Blaser WJ, Shanungu GK, Edwards PJ, Olde Venterink H. 2014. Woody encroachment reduces nutrient limitation and promotes soil carbon sequestration. Ecology and Evolution 4 : 1423-1438.

Bower CA, Reitemeier RF, Fireman M. 1952. Exchangeable cation analysis of saline and alkali soils. Soil Science 73 : 251-261.

Bremer JM, Mulvaney CS. 1982. Nitrogen total. In: Page, A.L., Miller, R.H., Keeney, R.R. (Eds.), Methods of Soil Analysis, Part 2. Second ed. American Society of Agronomy, Madison, WI: $595-624$.

Briggs JM, Knapp AK, Blair JM, Heisler JL, Hoch GA, Lett MS, Mccarron JK. 2005. An ecosystem in transition: Causes and consequences of the conversion of mesic grassland to shrubland. Bioscience55 : 243254.

Casals P, Romero J, Rusch GM, Ibrahim M. 2013. Soil organic C and nutrient contents under trees with different functional characteristics in seasonally dry tropical silvo pastures. Plant and Soil . DOI: 10.1007/s11104013-1884-9.

Chen L, Li H, Zhang P, Zhao X, Zhou L, Liu T, Hu H, Bai Y, Shen H, Fang J. 2014. Climate and native grassland vegetation as drivers of the community structures of shrub-encroached grasslands in Inner Mongolia, China. Landscape Ecology 30 : 1627-1641.

Chernov TI, Tkhakakhova AK, Kutovaya OV. 2015. Assessment of diversity indices for the characterization of the soil prokaryotic community by meta-genomic analysis. Eurasian Soil Science 48 : 410-415.

Chiej R, 1984. The Macdonald encyclopedia of medicinal plants (Macdonald Encyclopedias). Published by Macdonald, USA: 447.

Chuong J, Huxley J, Spotswood EN, Nichols L, Mariotte P, Suding KN. 2016. Cattle as Dispersal Vectors of Invasive and Introduced Plants in a California Annual Grassland. Rangeland Ecology and Management69 : $52-58$.

Dewan ML, Famouri J. 1964. The soils of Iran. Food and Agriculture Organization of the United Nations. Rome 318 .

Ding L, Wang P, Zhang W, Zhang Y, Li S, Wei X, Chen X, Zhang Y, Yang F. 2019. Shrub encroachment shapes soil nutrient concentration, stoichiometry and carbon storage in an abandoned subalpine grassland.Sustainability 11 : 1732. https://doi.org/10. 3390/su11061732.

Du BM, Ji HW, Peng C, Liu XJ, Liu CJ. 2016. Altitudinal patterns of leaf stoichiometry and nutrient resorption in Quercus variabilis in the Baotianman Mountains, China. Plant Soil 413 : 193-202. 
Eldridge DJ, Bowker MA, Maestre FT, Roger E, Reynolds JF, Whitford WG. 2011. Impacts of shrub encroachment on ecosystem structure and functioning: towards a global synthesis. Ecological Letters14 : 709-722.

Erfanzadeh R, Shahbazian R, Zali H. 2014b. Role of plant patches in preserving flora from the soil seed bank in an overgrazed high-mountain habitat in northern Iran. Journal of Agricultural Science and Technology 16 $: 229-238$.

Erfanzadeh R, Hazhir Sh, Jafari M. 2019. Effect of cushion plants on soil seed bank in overgrazed semi-arid regions. Land Degradation and Development. DOI: 10.1002/ldr.3517.

Erfanzadeh R, Bahrami B, Motamedi J, Petillon J. 2014a. Changes in soil organic matter driven by shifts in co-dominant plant species in a grassland. Geoderma 213 : 74-78.

Eskandarie B. 2012. History and status of soil survey in Iran, GSP regional workshop. The Islamic Republic of Iran Ministry of Jihad-e Agriculture, Iran : 25.

Foronda A, Pueyo Y, Arroyo AI, Saiz H, De la Luz Giner M, Alados CL. 2019. The role of nurse shrubs on the spatial patterning of plant establishment in semi-arid gypsum plant communities. Journal of Arid Environments 160 : 82-90.

Garcia Sanchez R, Camargo Ricalde SL, Garcia Moya E, Luna Cavazos M, Romero Manzanares A. Manuel Montano N. 2012. Prosopis laevigataand Mimosa biuncifera (Leguminosae), jointly influence plant diversity and soil fertility of a Mexican semiarid ecosystem.Revista de Biologia Tropical 60 : 87-103.

Garner W, Steinberger Y, 1989. A proposed mechanism for the creation of 'fertile islands' in the desert ecosystem. Journal of Arid Environmental 16 : 257-262.

Gazol A, Tamme R, Takkis K, Kasari L, Saar L, Helm A, Partel M. 2012. Landscape and small scale determinants of grassland species diversity, Direct and indirect influences. Ecography 35 : 944-951.

Geravand Y, Hosseini SM, Ahmadi K, Ghovmi Avili A, Ahmadi AR. 2016. Study on the Pisticia atlantica population structure in grazed and ungrazed areas (Yazd province, Baghshad). Natural Ecosystems in Iran $7: 89-102$.

Gomez Rey MX, Madeira M, Gonzalez Prieto SJ, Coutinho J, 2013. Soil C and N dynamics in a Mediterranean oak woodland with shrub encroachment. Plant Soil 371 : 339-354.

Gonzalez SL, Ghermandi L. 2019. Dwarf shrub facilitates seedling recruitment and plant diversity in semiarid grasslands. Plos One14 : e0212058. DOI: 10.1371/journal.

Guidi C, Vesterdal L, Gianelle D, Rodeghiero M. 2014. Changes in soil organic carbon and nitrogen following forest expansion on grassland in the Southern Alps. Forest Ecology and. Management 328 : 103-116.

Guo YC, Schob W, Ma A, Mohammat H, Liu S, Yu Y, Jiang B, Schmid Z. 2019. Increasing water availability and facilitation weaken biodiversity-biomass relationships in shrublands. Ecology 100: e02624. DOI: 10.1002/ecy.2624.

Hagos MG, Smit GN. 2005. Soil enrichment by Acacia mellifera subsp. detinens on nutrient poor sandy soil in a semi-arid southern African savanna. Journal of Arid Environmental 61 : 47-59.

Hammer Q, Harper DAT, Ryan PD. 2001. Paleontological statistics software package for education and data analysis. Palaeontologia Electronica 4 .

Heady HF, Child RD. 1994. Rangeland Ecology and Management. Westview press, USA. 520p.

Homer CD, Pratt PF. 1961. Methods of Analysis for Soils, Plants and Waters. University of California, Agricultural Sciences Publications, Berkeley, CA, 309 p. 
Hu PL, Liu SJ, Ye YY, Zhang W, Wang KL, Su YR. 2018. Effects of environmental factors on soil organic carbon under natural or managed vegetation restoration. Land Degradation and Development29 , 387-397.

Iyengar SB, Bagchi S, Barua D, Mishra C, Sankaran M. 2017. A dominant dwarf shrub increases diversity of herbaceous plant communities in a Trans-Himalayan rangeland. Plant Ecology 218 : 843-854.

Khodaparast A, Sayyah M, Sardari S. 2012. Anticonvulsant Activity of Hydroalcoholic Extract and Aqueous Fraction of Ebenus stellata in Mice. Iranian Journal of Basic Medical Sciences 15 : 811-819.

Kondo J, Hirobe M, Yamada Y, Undarmaa J, Sakamoto K, Yoshikawa K. 2012. Effects of Caragana microphylla patch and its canopy size on "islands of fertility" in a Mongolian grassland ecosystem.Landscape and Ecological Engineering 8: 1-8.

Kulmatiski A, Beard KH. 2013. Woody plant encroachment facilitated by increased precipitation intensity.Nature Climate Change3 : 833-837.

Li H; Shen H; Chen L; Liu T; Hu H; Zhao X; Zhou L; Zhang P, Fang J. 2016. Effects of shrub encroachment on soil organic carbon in global grasslands. Scientific Reports 6 :28974.

Li H; Shen H; Zhou L, Zhu Y, Chen L, Hu H, Zhang P; Fang J. 2019. Shrub encroachment increases soil carbon and nitrogen stocks in temperate grasslands in China. Land Degradation and Development. DOI: 10.1002/ldr.3259.

Liu MY, Chang QR, Qi YB, Liu J, Chen T. 2014. Aggregation and soil organic carbon fractions under different land uses on the tableland of the Loess Plateau of China. Catena 115 : 19-28.

Liu S, Zhang W, Wang K, Pan F, Yang S, Shu S. 2015. Factors controlling accumulation of soil organic carbon along vegetation succession in a typical karst region in Southwest China. Science of the Total Environmental 521 : $52-58$.

Maestre FT, Bowker MA, Puche MD, Hinojosa MB, Martinez I. 2009. Shrub encroachment can reverse desertification in semi-arid Mediterranean grasslands. Ecology Letters 12 : 930-941.

Maestre FT, Bautista S, Cortina J. 2003. Positive, negative, and net effects in grass-shrub interactions in mediterranean semiarid grasslands. Ecology 84 : 3186-3197.

Maestre FT, Cortina J. 2005. Remnant shrubs in Mediterranean semi-arid steppes, effects of shrub size, abiotic factors and species identity on understorey richness and occurrence. Acta Oecological 27: 161-169.

McClaran MP, Moore Kucera J, Martens DA, Van Haren J, Marsh SE. 2008. Soil carbon and nitrogen in relation to shrub size and death in a semi-arid grassland. Geoderma 145, 60-68.

Mozaffarian M, 2012. Recognition of medicinal and aromatic herbs in Iran, Moaser Publisher, Iran.

Mussa M, Ebro A, Nigatu L. 2016. Impact of woody plants species on soil physio chemical properties along grazing gradients in rangelands of eastern Ethiopia. Tropical and Subtropical Agroecosystems 19 : 343 - 355.

Noumi Z. 2015. Effects of exotic and endogenous shrubs on understory vegetation and soil nutrients in the south of Tunisia. Journal of Arid Land 7 : 481-487.

Oksanen J, Blanchet FG, Friendly M, Kindt R, Legendre P, McGlinn D, Minchin PR, O'Hara RB, Simpson GL, Solymos P, Stevens MHH, Szoecs E, Wagner H. 2019. Vegan: Community Ecology Package. R package version 2.5-5. https://CRAN.R-project.org/package=vegan.

Parizek B, Rostagno CM, Sottini R. 2002. Soil erosion as affected by shrub encroachment in northeastern Patagonia. Journal of Range Management 55 : 43-48.

Piper FI, Fajardo A, Baeza G. 2019. The association between a nurse cushion plant and a cluster root-bearing tree species alters the plant community structure.Journal of Ecology. DOI: 10.1111/1365-2745.13188. 
Ratajczak Z, Nippert JB, Collins SL. 2012. Woody encroachment decreases diversity across North American grasslands and savannas. Ecology 93 : 697-703.

Ren H, Yang L, Liu N. 2008. Nurse plant theory and its application in ecological restoration in lower subtropics of China. Progress in Natural Science 18: 137-142.

Sahebzadeh S, Heidari A, Kamelnia H, Baghbani A. 2017. Sustainability features of Iran's vernacular architecture: a comparative study between the architecture of hot-arid and hot-arid-windy regions.Sustainability 9: 749 .

Soliveres S, Maestre FT, Eldridge DJ, Delgado Baquerizo M; Quero JL; Bowker MA; Gallardo A. 2014. Plant diversity and ecosystem multifunctionality peak at intermediate levels of woody cover in global drylands. Global Ecology and Biogeography 23 : 1408-1416.

Sorkheh K, Kiani S, Sofo A. 2016. Wild almond (Prunus scopariaL.) as potential oilseed resource for the future: Studies on the variability of its oil content and composition. Food Chemistry212 : 58-64.

Stevens N, Lehmann CE; Murphy BP, Durigan G. 2017. Savanna woody encroachment is widespread across three continents. Global Change Biology23 : 235-244.

Throop HL, Lajtha K, Kramer M. 2013. Density fractionation and ${ }^{13}$ Creveal changes in soil carbon following woody encroachment in a desert ecosystem. Biogeochemistry 112 : 409-422.

Wiegand K, Ward D, Saltz D. 2005. Multi-Scale Patterns and Bush Encroachment in an Arid Savanna with a Shallow Soil Layer. Journal of Vegetation Science 16 : 311-320.

Whitford WG. 1992. Biogeochemical consequences of desertification. The Science of Global Change 18 : 852-359.

Xie Y, Wittig R. 2004. The impact of grazing intensity on soil characteristics of Stipa grandis and Stipa bungeana steppe in northern China (autonomous region of Ningxia). Acta Oecologica25 : 197-204.

Zeng Q, Liu Y, Fang Y, Ma R, Lal R, An S, Huang Y. 2017. Impact of vegetation restoration on plants and soil C: N: P stoichiometry on the Yunwu Mountain Reserve of China. Ecological Engineering 109 : 92-100.

Zhou L, Li H, Shen H, Xu Y, Wang Y, Xing A, Fang J. 2017. Shrub-encroachment induced alterations in input chemistry and soil microbial community affect topsoil organic carbon in an Inner Mongolian grassland. Biogeochemistry 136 : 311-324

Zibaeenezhad MJ, Shahamat M, Mosavat SH, Attar A, Bahramali E. 2017. Effect of Amygdalus scoparia kernel oil consumption on lipid profile of the patients with dyslipidemia: a randomized, open-label controlled clinical trial. Oncotarget $8: 1-6$.

\section{Figure captions}

Figure 1. Sampling areas had three shrub species ofAmygdalus scoparia (A), Daphne mezereum (B) andEbenus stellata $(\mathrm{C})$ that formed woody patches in the surrounding herbaceous vegetation, used as control (D) for comparing soil and vegetation characteristics, Marvast semiarid rangelands, Yazd province, Iran.

Figure 2. Mean (+- SE) soil properties under three shrubs:Amygdalus scoparia, Daphne mezereum and Ebenus stellata and herbaceous vegetation as control, Marvast semiarid rangelands, Yazd province, Iran. Lower case letters indicate statistically significant differences $(P<0.05)$ among patch types.

Figure 3. Non-metric multidimensional scaling (NMDS) of soil properties ( $R 2=0.98$ for Non-metric fit, $\mathrm{R} 2=0.95$ for Linear fit and Stress=0.01) under the three shrubs and herbaceous vegetation as control (A.m: Amygdalus scoparia, D.m: Daphne mezerum E.s=Ebenus stellata, cl: control).

Figure 4. Non-metric multidimensional scaling (NMDS) of plant composition according to the plant cover composition ( $\mathrm{R} 2=0.94$ for Non-metric fit, $\mathrm{R} 2=0.66$ for Linear fit and Stress $=0.03$ ) under the three shrubs 
and herbaceous vegetation as control (A.m: Amygdalus scoparia, D.m: Daphne mezerum E.s= Ebenus stellata, cl: control).

\section{Table captions}

Table 1) the results of one-way ANOVA for comparing soil properties between four locations including of three shrubs and herbaceous vegetation as control. Significant differences are shown using bold format.

Table 2) Mean vegetation characteristics and soil surface temperature in four locations including of three shrubs and herbaceous vegetation as control. Significant differences are shown using small letters according to the results of ANOVA and post-hoc tests.

Table 1) the results of one-way ANOVA for comparing soil properties between four locations including of three shrubs and herbaceous vegetation as control. Significant differences are shown using bold format.

\begin{tabular}{lllll}
\hline Soil properties & df & Mean Square & $\mathrm{F}$ & $\mathrm{p}$ \\
\hline $\mathrm{pH}$ & 3 & 0.34 & 20.99 & $<0.01$ \\
$\mathrm{EC}$ & 3 & 0.06 & 10.55 & $<0.01$ \\
$\mathrm{~K}$ & 3 & 471652.00 & 12.01 & $<0.01$ \\
$\mathrm{Ca}$ & 3 & 9622473.93 & 1.30 & 0.28 \\
$\mathrm{Mg}$ & 3 & 58274.48 & 0.64 & 0.59 \\
$\mathrm{~N}$ & 3 & 0.43 & 30.27 & $<0.01$ \\
$\mathrm{P}$ & 3 & 8376.11 & 19.38 & $<0.01$ \\
$\mathrm{OM}$ & 3 & 5.27 & 31.77 & $<0.01$ \\
\hline
\end{tabular}

Table 2) Mean vegetation characteristics and soil surface temperature in four locations including of three shrubs and herbaceous vegetation as control. Significant differences are shown using small letters according to the results of ANOVA and post-hoc tests.

\begin{tabular}{lllllll}
\hline & Amygdalus scoparia & Daphne mezerum & Ebenus stellata & control & $\mathrm{F}$ & $\mathrm{p}$ \\
\hline Shannon-Wiener index & $2.07 \mathrm{a}$ & $1.76 \mathrm{~b}$ & $1.41 \mathrm{c}$ & $1.10 \mathrm{~d}$ & 32.25 & $<0.01$ \\
Simpson index & $0.84 \mathrm{a}$ & $0.80 \mathrm{a}$ & $0.55 \mathrm{~b}$ & $0.80 \mathrm{a}$ & 7.64 & $<0.01$ \\
Menhinick index & $3.43 \mathrm{a}$ & $3.11 \mathrm{ab}$ & $1.46 \mathrm{c}$ & $2.50 \mathrm{~b}$ & 13.30 & $<0.01$ \\
Mean shrub height $(\mathrm{m})$ & $3.50 \mathrm{a}$ & $2.60 \mathrm{ab}$ & $1.83 \mathrm{~b}$ & - & 16.08 & $<0.01$ \\
Mean soil temperature $\left({ }^{\circ} \mathrm{C}\right)$ & $19.09 \mathrm{bc}$ & $17.93 \mathrm{c}$ & $20.74 \mathrm{~b}$ & $32.77 \mathrm{a}$ & 17.40 & $<0.01$ \\
Mean production $\left(\mathrm{g} / \mathrm{m}^{2}\right)$ & $32.15 \mathrm{~b}$ & $48.90 \mathrm{ab}$ & $64.76 \mathrm{a}$ & $16.09 \mathrm{c}$ & 8.23 & $<0.01$ \\
\hline
\end{tabular}

Appendix S1. Mean cover percentage and relative frequency (fi) of each plant species under each shrub and control area.

\begin{tabular}{|c|c|c|c|c|c|c|}
\hline Species & Daphne mezerum & fi & Amygdalus scoparia & fi & Ebenus stellata & fi \\
\hline Acantholimon sp. & 0.03 & 0.14 & 0.05 & 0.22 & 0.13 & 0.45 \\
\hline Acantholimon scorpius & 0.00 & 0.00 & 0.95 & 4.02 & 0.02 & 0.07 \\
\hline Acantophyllum spinosum & 0.01 & 0.05 & 0.00 & 0.00 & 0.00 & 0.00 \\
\hline Aegopordon berardioides & 0.07 & 0.31 & 0.00 & 0.00 & 0.00 & 0.00 \\
\hline Allium minutiflorum & 0.05 & 0.23 & 0.00 & 0.00 & 0.00 & 0.00 \\
\hline Allium sp. & 0.00 & 0.00 & 0.17 & 0.74 & 0.10 & 0.34 \\
\hline Alyssum marginatum & 0.11 & 0.53 & 0.67 & 0.28 & 0.00 & 0.00 \\
\hline Alyssum minus & 0.64 & 3.00 & 0.45 & 1.88 & 0.00 & 0.00 \\
\hline Alyssum sp. & 0.00 & 0.00 & 0.46 & 1.95 & 0.00 & 0.00 \\
\hline
\end{tabular}




\begin{tabular}{|c|c|c|c|c|c|c|c|}
\hline Species & Daphne mezerum & fi & Amygdalus scoparia & fi & Ebenus stellata & fi & $\mathrm{co}$ \\
\hline Amygdalus lycioides & 0.06 & 0.26 & 0.04 & 0.17 & 0.05 & 0.17 & 0. \\
\hline Amygdalus scoparia & 0.18 & 0.82 & 0.15 & 0.65 & 0.04 & 0.15 & 0. \\
\hline Angelonia sp. & 0.07 & 0.31 & 0.00 & 0.00 & 0.00 & 0.00 & 0. \\
\hline Artemisia aucheri & 0.40 & 1.88 & 0.53 & 2.23 & 1.48 & 5.01 & 0. \\
\hline Astragalus albispinus & 0.08 & 0.36 & 0.05 & 0.20 & 0.13 & 0.45 & 0. \\
\hline Astragalus podolobus & 0.07 & 0.33 & 0.06 & 0.24 & 0.06 & 0.19 & 0. \\
\hline Astragalus sp. & 0.01 & 0.06 & 0.10 & 0.42 & 0.00 & 0.00 & 0. \\
\hline Astragalus spachianus & 0.18 & 0.83 & 0.09 & 0.38 & 0.35 & 1.19 & 0. \\
\hline Astragalus terrestris & 0.00 & 0.00 & 0.08 & 0.33 & 0.00 & 0.00 & 0. \\
\hline Brassica sp. & 0.14 & 0.65 & 0.00 & 0.00 & 0.00 & 0.00 & 0. \\
\hline Bromus danthonia & 0.47 & 2.19 & 0.18 & 0.76 & 0.00 & 0.00 & 0. \\
\hline Bromus tectorum & 6.20 & 28.88 & 8.13 & 34.27 & 18.59 & 62.83 & 3. \\
\hline Centaurea virgata & 0.01 & 0.02 & 0.05 & 0.22 & 0.57 & 1.94 & 0. \\
\hline Clypeola aspera & 0.00 & 0.00 & 0.00 & 0.00 & 0.00 & 0.00 & 0. \\
\hline Convolvulus fruticosus & 0.00 & 0.00 & 0.22 & 0.93 & 0.00 & 0.00 & 0. \\
\hline Convolvulus sp. & 0.02 & 0.09 & 0.02 & 0.08 & 0.00 & 0.00 & 0. \\
\hline Crepis sancta & 0.00 & 0.00 & 0.29 & 1.24 & 0.00 & 0.00 & \\
\hline Daphne mezereum & 0.08 & 0.37 & 0.19 & 0.81 & 0.09 & 0.30 & \\
\hline Ebenus stellata & 0.01 & 0.02 & 0.07 & 0.31 & 0.22 & 0.75 & 0. \\
\hline Echinophora platyloba & 0.09 & 0.43 & 0.19 & 0.80 & 0.11 & 0.36 & 0 \\
\hline Erodium cicutarium & 0.00 & 0.00 & 0.13 & 0.55 & 0.00 & 0.00 & \\
\hline Erodium sp. & 0.05 & 0.24 & 0.06 & 0.25 & 0.00 & 0.00 & 0. \\
\hline Eryngium sp. & 0.00 & 0.00 & 0.09 & 0.40 & 0.40 & 1.35 & 0. \\
\hline Eryngium bangai & 0.02 & 0.07 & 0.12 & 0.52 & 0.08 & 0.26 & 0. \\
\hline Galium aparine & 3.06 & 14.26 & 2.04 & 8.60 & 0.29 & 0.99 & 1. \\
\hline Geranium sp. & 0.21 & 0.98 & 0.25 & 1.07 & 0.00 & 0.00 & \\
\hline Hertia angustifolia & 0.07 & 0.31 & 0.03 & 0.12 & 0.00 & 0.00 & \\
\hline Lactuca lanceolate & 0.03 & 0.13 & 0.24 & 1.02 & 0.25 & 0.86 & \\
\hline Lactuca orientalis & 3.25 & 15.12 & 0.45 & 1.89 & 0.31 & 1.04 & \\
\hline Lactuca serriola & 0.06 & 0.26 & 0.00 & 0.00 & 0.02 & 0.07 & \\
\hline Lolium perenne & 0.03 & 0.12 & 0.00 & 0.00 & 0.00 & 0.00 & \\
\hline Lolium sp. & 0.08 & 0.39 & 0.32 & 1.35 & 0.93 & 3.14 & \\
\hline Loranthus grewinkii & 0.06 & 0.29 & 0.00 & 0.00 & 0.00 & 0.00 & \\
\hline Marrubium vulgare & 0.00 & 0.00 & 0.52 & 2.20 & 0.00 & 0.00 & \\
\hline Medicago radiate & 0.43 & 1.99 & 0.49 & 2.07 & 1.28 & 4.32 & \\
\hline Micropus sp. & 0.15 & 0.68 & 0.46 & 1.93 & 0.00 & 0.00 & \\
\hline Myosotis sp. & 0.07 & 0.33 & 0.00 & 0.00 & 0.00 & 0.00 & \\
\hline Noaea mucronata & 0.12 & 0.55 & 0.11 & 0.47 & 0.20 & 0.68 & \\
\hline Onopordon sp. & 0.07 & 0.35 & 0.00 & 0.00 & 0.00 & 0.00 & \\
\hline Papaver sp. & 0.00 & 0.00 & 0.08 & 0.32 & 0.00 & 0.00 & \\
\hline Paracaryum sp. & 0.00 & 0.00 & 0.11 & 0.48 & 0.17 & 0.59 & \\
\hline Phlomis Aucheri boiss & 0.00 & 0.00 & 0.00 & 0.00 & 0.00 & 0.00 & 0. \\
\hline Poa annual & 0.00 & 0.00 & 0.46 & 1.92 & 0.00 & 0.00 & 0. \\
\hline Poa sinaica & 0.00 & 0.00 & 0.00 & 0.00 & 0.08 & 0.26 & 0. \\
\hline Psathyrostachys & 1.54 & 7.15 & 2.00 & 8.44 & 1.87 & 6.31 & 0 \\
\hline Scabiosa olivieri & 0.00 & 0.00 & 0.08 & 0.32 & 0.00 & 0.00 & 0. \\
\hline Schismus arabicus & 0.00 & 0.02 & 0.00 & 0.00 & 0.00 & 0.00 & \\
\hline Scirpoides holoschoenus & 0.00 & 0.00 & 0.04 & 0.16 & 0.00 & 0.00 & \\
\hline Scorzonera sp. & 0.11 & 0.50 & 0.00 & 0.00 & 0.00 & 0.00 & \\
\hline Senecio sp. & 0.00 & 0.00 & 0.02 & 0.08 & 0.00 & 0.00 & 0. \\
\hline
\end{tabular}




\begin{tabular}{llllllll}
\hline Species & Daphne mezerum & $\mathrm{fi}$ & Amygdalus scoparia & $\mathrm{fi}$ & Ebenus stellata & $\mathrm{fi}$ & cont \\
\hline Stachys inflate & 0.00 & 0.00 & 0.20 & 0.86 & 0.00 & 0.00 & 0.12 \\
Sterigmostemum longistylum & 0.00 & 0.00 & 0.04 & 0.16 & 0.00 & 0.00 & 0.00 \\
Stipa barbata & 0.17 & 0.79 & 0.20 & 0.83 & 0.58 & 1.95 & 0.31 \\
stipa parviflora & 0.00 & 0.00 & 0.04 & 0.18 & 0.15 & 0.50 & 0.07 \\
Valerianella oxyrhynchus & 1.26 & 5.87 & 0.78 & 3.28 & 0.62 & 2.09 & 0.13 \\
Ziziphora tenuior & 1.68 & 7.84 & 1.17 & 4.92 & 0.41 & 1.38 & 0.40 \\
Sum & 21.47 & 100.00 & 23.73 & 100.00 & 29.58 & 100.00 & 9.11 \\
\hline
\end{tabular}

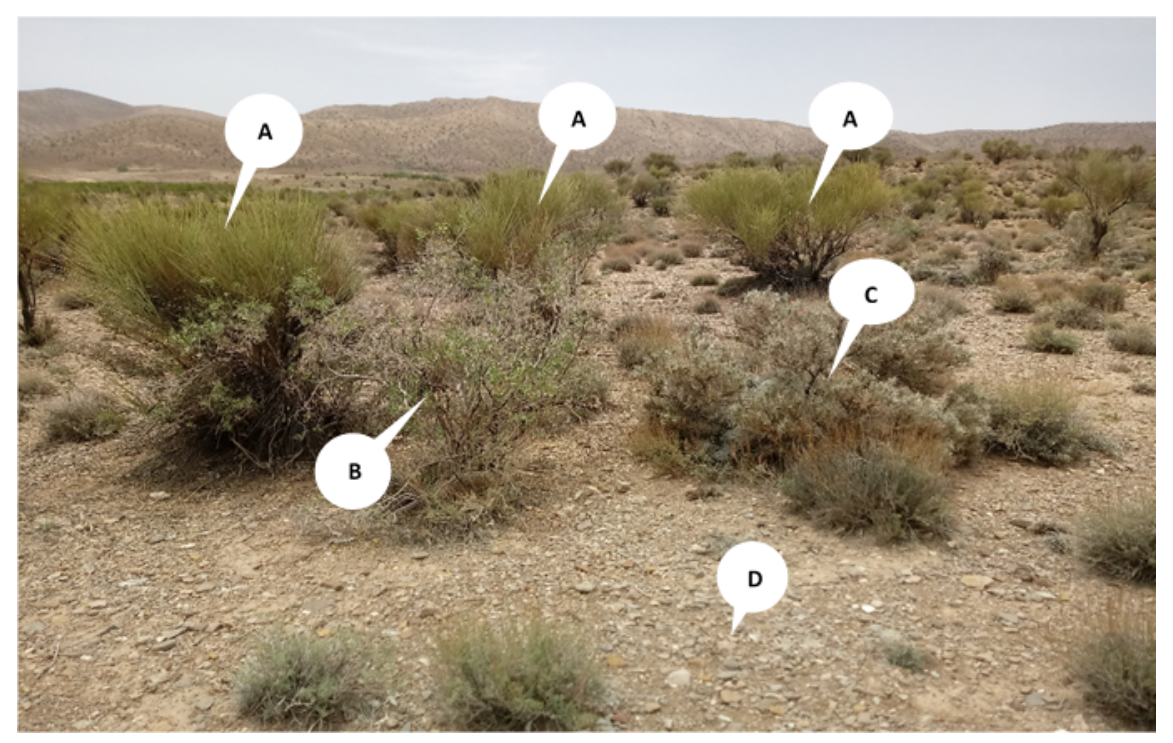



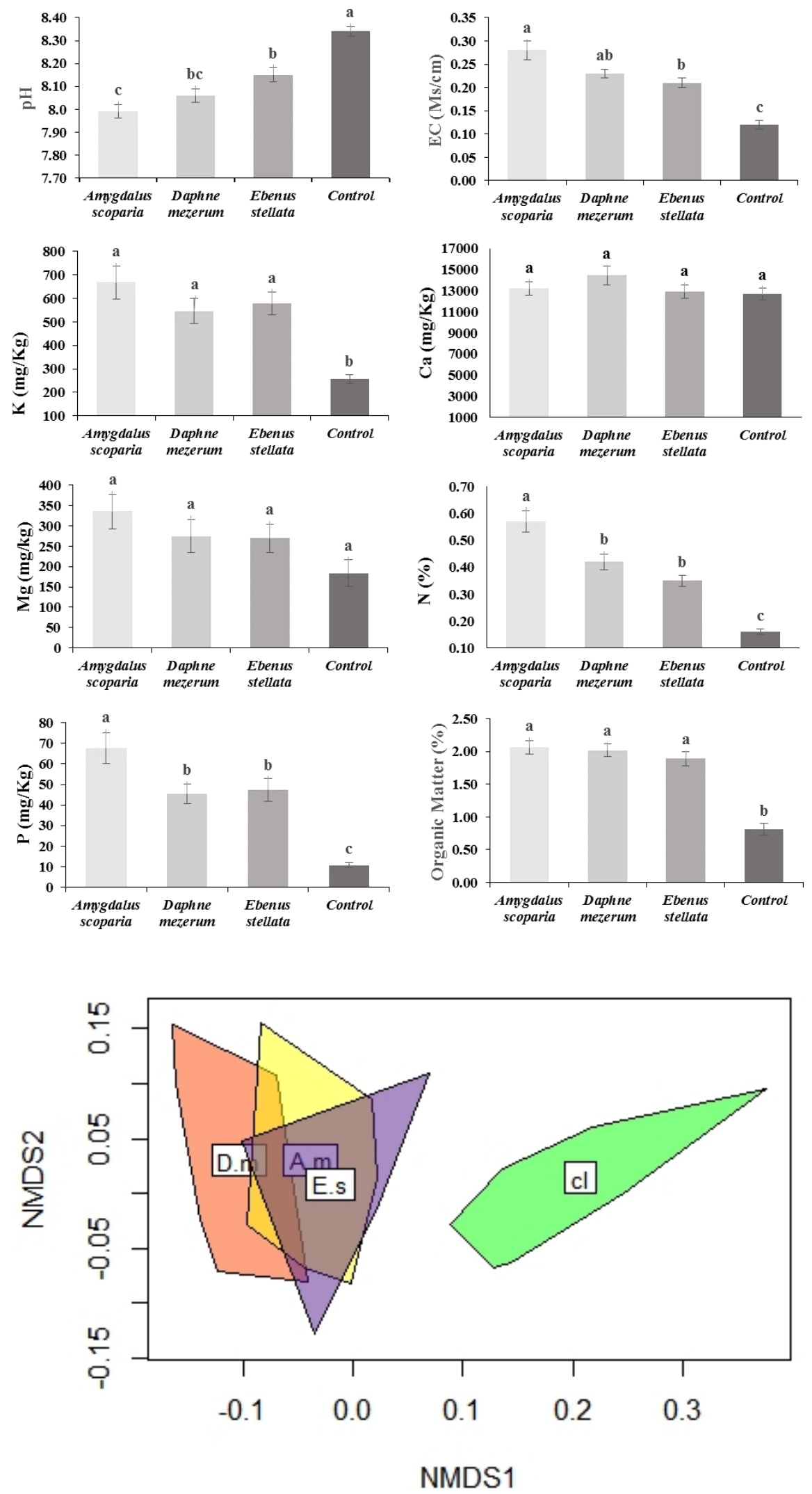


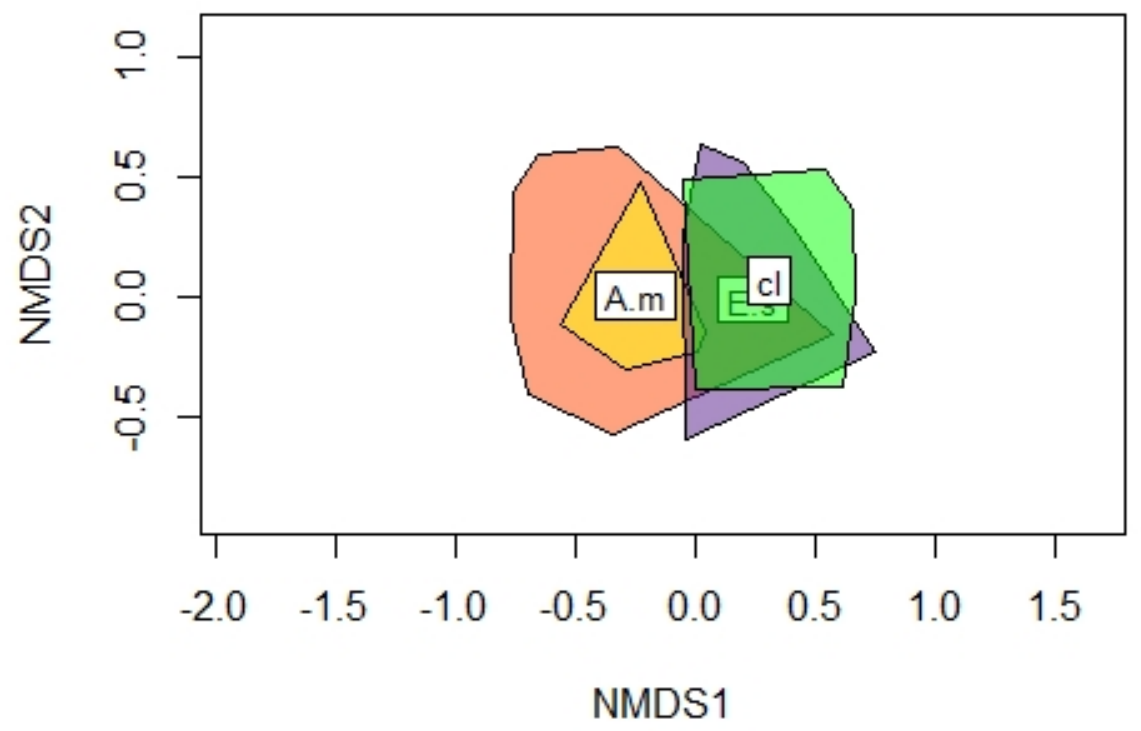

